author, who also makes the unsubstantiated claim that it was "shown in one of the main exhibition spaces" (168). Despite it being the work of an outside production company, the author uses it as evidence to shed light on the limits of the kind of activism that the CMHR endorses. There are valid criticisms that can, and should, be made about the limits of activist capacity at and through the CMHR. Suggesting, however, that an advertisement commissioned by the Friends of the CMHR - the fundraising arm of the museum - was core content in exhibition galleries is problematic. It creates an unfair reflection of the research, curatorial, and design decisions of CMHR employees for whom this advertisement was not their work.

Putting aside such concerns, the book is written in a thoughtful way. Robertson welcomes the reader in by personalizing the narrative and inserting herself as author at opportune points. This effectively guides the reader through her questions, research, and analysis in engaging ways, making the work as a whole a useful classroom textbook. The case studies that she explains are an irreplaceable resource for undergraduate and master's level students. Robertson delves into the ways workers in Canadian museums have developed their community engagement, collections, and advocacy portfolios. She is honest with how the process of writing this book changed her opinion on museum capacities in social justice and contemporary collecting. The colour photographs are beautifully printed; they help tell the stories that Robertson discusses here. For students of History, Art, Museum Studies, and Urban Planning, this book teaches the reader how museum spaces, art galleries, and movements around remembrance have been politicized, co-opted, and/or mobilized within these institutions in the Canadian context over the course of the twentieth century. Robertson's work remains important to the field at large and will continue to be interrogated by scholars for years to come.

Carly Ciufo

McMaster University

\title{
Michelle Purdy \\ Transforming the Elite: Black Students and the Desegregation of Private Schools
}

Chapel Hill: University of North Carolina Press, 2018. 258 pp.

Michelle Purdy's meticulously researched book examines racial desegregation in historically white elite schools in the 1960s and 1970s. Drawing on board meeting minutes, national reports, bulletins, school newspapers, and oral histories, she interrogates how and why school leaders decided to admit black students even though the Brown v. Board of Education Supreme Court decision only applied to public schools. Purdy focuses on The Westminster Schools (Westminster) in Atlanta, Georgia, and she details how politics at the local, regional, and national levels influenced decisions and culture at this school. Purdy makes two primary arguments. First, she asserts that social, political, and economic changes impacted private schools. Thus, 
she successfully troubles the dichotomy between public and private. Second, Purdy contends that black students bravely navigated schools that were not built for them. Their "priceless inheritance" (45), the uplifting experiences they had in southern black segregated communities and schools, helped them to succeed at Westminster and shape the school's culture. Transforming the Elite is an institutional, social, and intellectual history that expands the racial school desegregation narrative and adds depth to understanding black students' experiences in historically white schools.

Purdy links the institutional and the national through her discussion of Westminster's founding President, Dr. William Pressly, who also served as a national independent school leader. Pressly and other independent school administrators grappled with the changing political climate and how it should influence private school admission policies and school culture. Although Pressly did not initially speak publicly against segregation, by the 1970s, he openly suggested that the federal government "ensure integrated, adequate, and equal education in both public and private schools" (147). Independent school leaders around the country implemented open admission policies, discussed race in national publications, implemented new initiatives, and recruited black students.

Desegregation policies in Atlanta Public Schools (APS) also influenced policies at Westminster, further buttressing Purdy's argument about the connection between public and private sectors. Westminster board members anticipated white flight from public schools to private schools with an end to de jure segregation in APS, so they agreed in 1958 to raise testing fees and change enrollment policies to deter potential applicants. As predicted, applications at Westminster increased through the early 1970s as white parents sought a racially homogenous school environment for their children, and black parents sought academic rigor and better resources for their children.

Purdy cogently identifies three incentives for independent school leaders to integrate their schools. First, they had a moral incentive to uphold the principles of the civil rights movement and distinguish their schools from segregationist academies. In the case of Westminster, black Atlantans wrote letters to Pressly about the school's admissions policies, which helped put pressure on Pressly to open the school to black students. Second, there was a financial incentive since the federal government threatened and eventually stipulated that private schools have anti-discriminatory policies to receive tax-exemption status. School leaders also wanted to maintain their elite private school's positive public image and growth. The third incentive was independent school leaders' desire to align with societal shifts regarding desegregation, mainly because their schools served as a pipeline to colleges and universities that desegregated or began to promote racial inclusion.

Purdy also captures both the "psychological scarring" (114) that African American students endured and their resistance and resilience in what is the most engaging section of the book. Drawing on extensive oral histories, Purdy details specific instances of quotidian racial harassment. White students collectively assaulted Michael McBay on his first day of eighth grade. Joia Johnson encountered racism for the first time in the fifth grade when a white classmate called her "a little black sambo nigger" (136) 
during a basketball game. Jannard Wade recalls a football coach making a racist remark to the team after practice.

Black students resisted the racist school climate at Westminster and thrived socially and academically despite their struggles. Michael McBay wrote articles and drew cartoons for the student newspaper that critiqued tokenism and "subtle hostilities" (153) at Westminster, among other issues at the school and national events relating to black life. Purdy asserts that McBay joined the ranks of young people involved in social activism in the late 1960s and early 1970s, reminding readers that the events at Westminster were connected to local, regional, and national events. Purdy also notes that the African American students' resiliency stemmed from the support they received from each other, black workers at the school, and select white teachers and classmates. Black students' social life in the black community outside of school, including participation in church events and social clubs, was also critical to their success. Purdy skillfully avoids any implication that black segregated schools were inherently inferior to historically white elite schools by emphasizing the strong foundation that segregated black schools provided for the students that desegregated Westminster.

Although independent schools did not experience a complete transformation after the initial years of desegregation, they showed signs of progress. At Westminster, aspects of the overtly racist school culture, including the annual slave auction fundraiser, quietly disappeared. Students selected Corliss Blount as Miss Mardi Gras three years after she desegregated the girls' dormitory in 1970. One white Westminster alumnus reflected that he had greater respect for different racial groups due to his interactions with black students at school. Purdy aptly describes the school culture as "complex and contradictory" (7).

Purdy concludes the book with a compelling analysis of how the history of school desegregation reveals how schools can perpetuate and challenge racist narratives, the ongoing need for studying change on the institutional and interpersonal levels, and contemporary challenges of school choice. For example, Purdy suggests that considering the role of private schools in the education of African Americans will add depth to conversations about contemporary neoliberalism in the education sphere in which some portray minority students as victims. As the successful career trajectory of the students that desegregated Westminster demonstrates, African Americans have benefitted from private schooling. Transforming the Elite enriches scholarship on desegregation and the educational experiences of black children in the United States.

Ashley Dennis 